\title{
Does the Structural Organisation of Lower-Secondary Education in Switzerland Influence Students' Opportunities of Transition to Upper-Secondary Education? A Multilevel Analysis ${ }^{1}$
}

\author{
Katja Scharenberg ${ }^{*}$, Karin Wohlgemuth**, and Sandra Hupka-Brunner***
}

Abstract: The Swiss cantonal education systems account for the structural organisation of lower-secondary education (streamed, cooperative or integrated models). We examined whether structural cantonal variations affect students' transition to upper-secondary education. Analyses drew on data from the TREE study. Multilevel logistic regression analyses indicated that students in cantons with a cooperative or integrated model had, by trend, a higher chance of gaining access to upper-secondary education. The effect was confounded with the language regions.

Keywords: educational trajectories, education systems, structural model, Switzerland, multilevel modelling

\section{Effekte der Selektion im schweizerischen Bildungssystem auf den Übergang in die postobligatorische Ausbildung. Eine Mehrebenenanalyse}

Zusammenfassung: Der Beitrag untersucht, ob kantonale Unterschiede in der Organisation des schweizerischen Schulwesens in der Sekundarstufe I (geteiltes, kooperatives oder integriertes Modell) den Übergang in die postobligatorische Ausbildung beeinflussen. Logistische Mehrebenenanalysen anhand der TREE-Studie zeigen, dass Jugendliche aus Kantonen mit einem kooperativen oder integrativen Schulmodell tendenziell eine höhere Wahrscheinlichkeit haben, direkt in die postobligatorische Ausbildung einzusteigen. Der Effekt ist mit der Sprachregion konfundiert.

Schlüsselwörter: Bildungsverläufe, Bildungssystem, Schulmodell, Schweiz, Mehrebenenanalyse

\section{Les effets de la sélection au degré secondaire I sur la transition vers I'enseignement post-obligatoire en Suisse. Une analyse multiniveaux}

Résumé: Cet article examine l'influence des variations cantonales de l'organisation structurelle de la formation au degré secondaire I sur la transition vers l'enseignement post-obligatoire en Suisse. Les analyses logistiques multiniveaux réalisées à partir des données de l'étude TREE suggèrent que les élèves des cantons ayant un modèle coopératif ou intégré ont tendanciellement une plus grande probabilité d'accéder à une formation certifiante au niveau post-obligatoire. L'effet se confond avec celui de la région linguistique.

Mots-clés: parcours de formation, système éducatif, modèle de structure, Suisse, analyses multiniveaux

\footnotetext{
* Institute of Sociology, University of Education Freiburg, D-79117 Freiburg, katja.scharenberg@ ph-freiburg.de.

** Statistik Aargau, Kanton Aargau, CH-5000 Aarau, karin.wohlgemuth@unibas.ch.

*** Institute of Sociology, University of Bern, CH-3012 Bern, sandra.hupka@soz.unibe.ch.

1 The authors would like to thank two anonymous reviewers for their helpful comments on an earlier draft of this paper.
} 


\section{Introduction}

Educational transitions ${ }^{2}$ play an important role in determining adolescents' future educational careers. After primary school, students in Switzerland are allocated to different tracks in lower-secondary school. On the one hand, these tracks constitute differential environments for students' learning and development (Baumert et al. 2006). On the other hand, they work as "labels" and signals of students' ability according to which training companies or upper-secondary schools select their applicants (e. g. Moser et al. 2002; Imdorf 2009). In Switzerland, the cantonal authorities determine the structural organisation of lower-secondary education. They define criteria for the transition from primary to lower-secondary education and which structural model is applied in secondary education (Swiss Education Server 2016): While most cantons apply some form of ability-based streaming with different tracks, other cantons adopt either a cooperative structural model (ability-based assignment and regrouping for selected subjects) or an integrated structural model (non-selective classes with regrouping for selected subjects). In some cantons, different structural models coexist. The educational provision at lower-secondary level in Switzerland is thus characterised by considerable structural variations between the cantons.

In contrast to comparisons on a country level, this article applies a subnational approach. ${ }^{3}$ As the educational offer and its cantonal particularities shape students' structural environment and individual opportunities, these differences then again may have an influence on successful educational careers. Therefore, the present article examines how the structural organisation of lower-secondary education, i. e. the cantonal differences in students' allocation amongst tracks, influence their educational pathways and transition to a certifying general or vocational education on upper-secondary level.

We will begin with the theoretical embedment of the research question, followed by an overview of the transitions and selection criteria within the different cantonal educational systems in Switzerland. Subsequently we will examine the transition to upper-secondary education. Empirical analyses will draw upon data on transition processes from the Swiss Conference of Cantonal Ministers of Education (EDK) and the Swiss Transitions from Education to Employment (TREE) study.

2 Educational transitions, transition, allocation, pathway and trajectories are used synonymously.

3 Other studies applying subnational approaches for Switzerland focused e. g. on the impact of cantonal education systems on gender-typical school-to-work transitions (Imdorf et al. 2014) or the influence of political measures on cantonal level on women's employment behaviour (Stadelmann-Steffen 2007). 


\section{Theoretical frame and current state of research}

Transitions within educational systems can be pivotal moments, as they determine individual educational pathways and exacerbate social inequalities (Eckert 2007; Autorengruppe Bildungsberichterstattung 2008; Ditton and Maaz 2011). With the beginning of primary school, educational opportunities are unequally distributed depending on students' social origin (e. g. Moser et al. 2005; Buchmann and Kriesi 2010). These social inequalities are reinforced throughout students' educational trajectories, e.g. at the transition from primary to lower-secondary school (Ditton and Krüsken 2006; Maaz et al. 2010b) or at the transition from lower to upper-secondary school (Konietzka 2008). Social inequalities can be observed with regard to competences, values, interests and self-concepts, which all are significant for educational decisions and transitions, so that social inequalities are most likely to become manifest during the transition from primary school to lower-secondary education (Maaz et al. 2010a). From an international comparative perspective, especially early tracking and segmented secondary education seem to be linked with higher levels of social inequalities (Pfeffer 2008).

In order to explain mechanisms of how social inequalities shape educational transitions, one can draw upon Boudon's (1974) theoretical model of primary and secondary effects of social origin. On the one hand, differences in support and parenting styles act as primary effects of social origin during school, and produce different levels of school performances. On the other hand, secondary effects of social origin play a significant role for the transitions between educational levels: They consist of family educational decisions that precede transitions and are based on differing assessments depending on parental social background. Secondary effects of social origin are of special importance, as they lead to a constant reproduction of social inequality of educational opportunities with each transition across the life span (Becker 2011). Other theoretical explanations focus on family resources (Bourdieu and Passeron 1971) and the supportive effects of reference persons (Neuenschwander et al. 2012). According to Bourdieu (1983), the acknowledgement of social, cultural and economic capital differs according to the social field. Whether and how different forms of capital can be converted depends on field-specific conditions and rules. This raises the question to what extent institutions and their gatekeepers take into account the resources that are available to students (Eberhard and Ulrich 2010; Ulrich 2012).

From a theoretical perspective, both individual decisions and resources as well as institutional framework conditions define the scope of action and need to be taken into account to explain educational transitions (Hillmert 2004). Life span centred analyses represent such an approach, assuming that state institutions have a central structuring effect and shape individual biographies (Hillmert 2004; Levy et al. 2005). This life span perspective (Elder 1975; Blossfeld et al. 2011) emphasises 
that early educational stages can have a high impact on later developments (e.g. educational trajectories and employment careers).

\section{Selection thresholds in the Swiss educational system}

In Switzerland, the compulsory education contains two transitions. Until the implementation of HarmoS, the first transition took place after the completion of primary education after four to six years. After nine compulsory school years, students are directed into vocational or general tracks on upper-secondary level. Even if students were able to make a decision based on their abilities and talents rather than on stereotypes, biased expectations or discrimination (Coradi Vellacott and Wolter 2005) as well as their socio-economic background (Hupka-Brunner et al. 2011a) shape these transitions. Research findings suggest that students' ascriptive attributes (e.g. socio-cultural origin, gender) influence selection processes during the transition from primary to secondary education (e. g. Ditton and Krüsken 2006; Kronig 2007). In the case of Germany, substantial inequalities arise at the transition to lower-secondary school and are difficult to address later in students' educational career (Ditton and Krüsken 2006; Maaz et al. 2010b). In the case of Switzerland, research findings indicate that streamed models are more likely to increase than decrease social inequalities (Brosziewski and Nido 2005). Furthermore, selection processes may be of low prognostic quality as the selection procedure does not fully ensure a fair and sound selection to secondary school tracks (Baeriswyl et al. 2009). Such debates point to the importance of the institutional regime in which students are imbedded. Besides, previous studies emphasised substantial differences in educational enrolment (FSO 2003) and young adults' attainment (Scharenberg et al. 2016) by language region in Switzerland: Enrolment in and completion of vocational education and training was found to be higher for students in German-speaking cantons than among those in French- or Italian-speaking parts of the country. On the one hand, this could be due to different educational norms - e.g. students in the French-speaking part of Switzerland are oriented toward general academic education, whereas many perceive vocational education as a second-rate option (e.g. Geser 2003). On the other hand, the demand and opportunity structures of the education system differ between the language regions, as the ratio between academic and dual vocational education and training (VET) programmes varies between (cantons and) language regions (Seibert et al. 2009) and the labour market situation is also quite different in the three language regions. Imdorf et al. (2014) showed that the ratio between general academic and dual VET programmes in post-compulsory education differs greatly between the cantons: In French- and Italian-speaking cantons (taken together as "Latin-speaking Switzerland"), students were more likely to be enrolled in academic programmes than in dual VET programmes. Because those 
educational offers are used differently, the differences between the language regions play a central role in our analyses. Although the predominant structural model in lower-secondary education can be identified for each canton, up to now, little is known about its effects on students' transition to upper-secondary level.

\subsection{Transition from primary to lower-secondary education and diversity of structural models within lower-secondary education}

The first educational transition takes place when students leave the three- to fouryear primary school and enter lower-secondary education. Depending on cantonal and communal authorities, lower-secondary education is organised in streamed, cooperative or integrated structural models. The streamed model consists of classes with differing performance levels in all subjects (two to four tracks). The cooperative model requires students to visit core classes with performance requirements. The main subjects (usually the native language and a foreign language) are taught in separate classes according to students' performance, while the rest of the subjects are held in heterogeneous classes without any further performance differentiation. In integrated models, students attend heterogeneous core classes, whereas the main subjects are taught in separate classes that differentiate according to students' performance (Swiss Education Server 2016).

The allocation amongst performance classes is based on students' competences (marks, comparative testing), parents' wishes, attitudes towards learning and working, the expected likelihood of success and the students' wishes (Neuenschwander et al. 2012). The selection criteria depend on cantonal or communal regulations. Transition processes that rest upon objective performance measures may presumably lead to more equal opportunities. If such performance tests are used as "objective performance standards" and are not bound to previously set transition quotas, ${ }^{4}$ they should lead to a more reliable (and meritocratic) transition to upper-secondary education. Furthermore, for the German-speaking cantons Neuenschwander et al. (2012) showed that the composition of structural models in lower-secondary education affected the allocation of some groups of students: Boys less often attended a Gymnasium in cantons where only a few students were in academic tracks, and migrants were disadvantaged in cantons with four tracks.

The diversity of the structural models amongst the cantons was documented by the cantonal survey conducted by the EDK in the year $2000^{5}$ (Swiss Document Server Education 2009). Although some cantons applied more than one structural model, the cantonal survey indicated which model was the most prevalent. The

$4 \quad$ Kronig (2007) underlines that once school institutions for children with special educational needs exist, they are "filled" with learners, even if the set "limits" have to be adjusted.

5 We chose the year 2000 because it is the reference year for the TREE cohort. Lower-secondary education was in a process of reform during the last 30 years. In the course of this process, cooperative and integrated models were introduced to increase the permeability between the streams (FSO 2014). 
streamed model with separate tracks was the most common one, which is why all in all Switzerland can be described as a country with early and strong tracking (SCCRE 2010). A study in the canton of Zurich between 1999 and 2004 indicated that mobility in general was more prevalent in the cooperative model than in the streamed model. In the cooperative model there was a greater balance between upward and downward mobility whereas downward mobility was more prevalent in the streamed model (Moser 2008). In streamed models, however, individual changes between achievement levels seem to be hard to realise because they usually require a change of school so that permeability is mostly unidirectional, i. e. that students change to a lower track (see also Trautwein et al. 2007 for similar findings for Germany). In contrast, integrated and cooperative models are more flexible in terms of students' adaptation when changing achievement levels; therefore, they might provide a better match between students' actual capabilities and their school level. In this regard, in a subnational comparison, a recent study for Germany found that structural models with a later tracking led to lower educational inequalities due to a higher permeability especially for children with a low socioeconomic status (SES) (Büchler 2016).

\subsection{Transition from lower-secondary education to upper-secondary education}

In Switzerland, the second significant transition takes place after lower-secondary education. After the end of compulsory education, adolescents at the age of about 16 years face the transition to post-compulsory education. This transition depends on individual student characteristics on the one hand, as well as on characteristics of the labour market and the functionality of the educational system on the other hand. In any case, this transition is embedded in the context of the respective educational system, which sets - with its institutional structure on cantonal level with regard to offerings and selection criteria especially for vocational education - the opportunities and trajectories of transition (Keller and Moser 2013; Keller 2014).

Vocational education, especially company-based education, is of great importance in Switzerland (SCCRE 2010), because the majority of adolescents gain their upper-secondary certificate in this track. Other upper-secondary tracks include the Gymnasium, which is completed by passing the baccalaureate and provides direct access to university, as well as the upper-secondary specialised middle schools, which can be completed by passing the specialised baccalaureate and thereby provide access to universities of applied sciences. These two forms of school-based academic education demand higher performances from the adolescents. A condition for the admission to such school-based upper-secondary tracks is usually the attendance of a track with extended requirements in lower-secondary education. Adolescents who do not manage the direct transition to upper-secondary education often enrol in bridge-year courses, internships or language courses; only a few do not attend any kind of educational programme at all (Keller et al. 2010). Such delayed entries into the upper-secondary level can have negative effects on adolescents' further education 
(e. g. Hupka-Brunner al. 2011a). The attendance of a basic track in lower-secondary education also increases the likelihood of discontinuous pathways in upper-secondary education (Hupka-Brunner et al. 2011a; Hupka-Brunner et al. 2011b).

The selection patterns that full-time school-based tracks, e. g. Gymnasium and upper-secondary specialised schools, exhibit are different to the ones of companybased tracks (Seibert et al. 2009). School-based tracks are more likely to be standardised and closely tied to school performances (Gentinetta and Zulauf 2001). The pattern of selection of company-based education differs according to the company size. Big companies usually use information about marks and attended tracks in lower-secondary education for an initial rough selection in order to reduce the big amount of applicants. Adolescents from basic tracks therefore usually have lower chances of being employed by big companies, because they have already been rejected during the first selection round. In addition, big companies often conduct their own assessments or rely on external assessments (multicheck; Moser 2004). The selection processes of small and medium-sized companies usually seem to be less standardised (Imdorf 2009). School performances are only relevant insofar as the successful graduation from a vocational school should be pursued. Small and medium-sized companies therefore offer low-achieving adolescents or those attending tracks with basic requirements realistic chances of completing an upper-secondary education. In many cases, apprentices have already completed an internship at the respective company, so the company already has an idea of how well applicants would fit into the company and how productive they are. However, empirical analyses (HupkaBrunner et al. 2010) showed that the chances of students from basic tracks were clearly compromised - independently whether they tried to enter a full-time school-based or a dual upper-secondary education. We therefore expected students in basic tracks to have a lower overall chance of successfully starting either an upper-secondary general education or VET even when controlling for further performance indicators, such as PISA reading competences or marks. Especially the attendance of basic tracks can make the transition to upper-secondary education difficult and increase the likelihood of adolescents' further education being discontinuous. Furthermore, the implemented structural model may as well have a signalling effect for the authorities that are responsible for the selection within upper-secondary education. One can suppose that the cooperative and the integrated structural models do not emit such clear labelling signals as the streamed model regarding students' subsequent education. For this reason, we assume that the structural model - provided the respective school performances are given - influences the transition to upper-secondary level. More precisely, we hypothesise that the cooperative or integrated structural models improve transition chances in contrast to the streamed model (for the derivation of our hypotheses cf. also Section 4).

Research findings showed that the structural model had an effect on students' chances of entering post-compulsory education on upper-secondary level (Hupka- 
Brunner and Wohlgemuth 2014). Controlling for gender, social origin, schooland achievement-related variables (e.g. reading literacy, marks in mathematics, attended school track) as well as cantonal characteristics (transition criteria, degree of urbanisation and language region), the cooperative structural model was found to significantly improve the chances of transition to post-compulsory education: Other things being equal, students from cantons with a cooperative model had a 1.5-times higher transition probability compared to those from cantons with other structural models. Hupka-Brunner and Wohlgemuth (2014) applied a binary logistic regression model to examine the effect of the structural model on successful transitions, but they did not take into account the structural model as a cantonal characteristic on a second level. In the present paper, however, we aim at consolidating these research findings by taking into account the nested data structure and applying a multilevel approach.

\section{$4 \quad$ Research question and hypotheses}

The present study explored effects of cantonal characteristics with regard to students' chance of transition from lower- to upper-secondary education. Based on the aforementioned theoretical considerations, our research questions (RQ) were as follows:

1. Does students' chance of transition from lower- to upper-secondary education vary between the cantons? (RQ1)

We hypothesised that there was a significant variation in students' transition probability to upper-secondary level due to cantonal differences $(\mathrm{H} 1)$, indicating the necessity of examining the effects of cantonal variables from a multilevel perspective.

2. Does the structural organisation of lower-secondary education in Switzerland have an effect on students' transition to upper-secondary level? (RQ2)

As outlined above, the attendance of different tracks in lower-secondary school serves as a signal for the selection of applicants for vocational education and training. The different tracks also constitute differential learning environments influencing educational outcomes such as achievement or trajectories - independently of and in addition to students' sociocultural origin. We thus hypothesised that students from cantons with a cooperative or integrated model had a higher chance of transition to certifying general or vocational education programmes on upper-secondary level than students in cantons with a streamed model (H2). This was in line with the findings by HupkaBrunner and Wohlgemuth (2014) based on the same dataset. However, in the present paper, we aimed at an advancement to these analyses and adopted a multilevel perspective, taking into account the hierarchical data structure and 
simultaneously controlling for characteristics on student and cantonal level with, however, a focus on the effect of the structural model.

\section{Data and methodology}

\subsection{The present study}

Analyses based on data from the Swiss youth panel survey TREE (Transitions from Education to Employment), which was the first and so far only longitudinal study in Switzerland that examined post-compulsory educational pathways of young adults and their entry into the labour market (TREE 2013c). The sample comprised around 6000 students who participated in the PISA (Programme for International Student Assessment) 2000 study and left compulsory school the same year. The sample was followed up in seven annual surveys between 2001 and 2007 with an eighth follow-up in 2010 and a ninth one in 2014 when participants reached an average age of 30 years. ${ }^{6}$ The sample was representative of Switzerland both on country level as well on the level of the language regions. Besides the Youth in Transition Survey (YITS) in Canada, TREE was the only panel survey worldwide based on the PISA 2000 sample. The study was mainly funded by the Swiss National Science Foundation (SNSF).

As the TREE data combined a measurement of basic literacy scores with a wide range of characteristics of students' socio-economic background, the schools' learning environment and some cantonal features assessed by PISA (TREE 2013b), it was possible to identify conducive and hindering conditions of successful transitions into upper-secondary education at different levels of analysis.

\subsection{Multilevel analyses}

Besides student characteristics, e. g. gender, socio-economic status (SES) and PISA reading literacy, which proved to be significant predictors of upper-secondary entry (Hupka-Brunner et al. 2010), our analyses also examined effects on cantonal level (e.g. structural models in upper-secondary education). In the present case, where the variables of interest were located at different levels (student and cantonal level), it was important to take into account the clustering of individuals within cantonal

6 Our long-term observation data would also allow to examine longer-term outcomes such as transitions into the labour market or highest obtained certificates in young adulthood. Our focus in the present study, however, was mainly a multi-level validation of the findings of Hupka-Brunner and Wohlgemuth (2014). Beyond that, the successful transition to certifying upper-secondary general education or VET programmes is a bottleneck with severe long-term consequences, e. g. for educational attainment in young adulthood (e. g. Scharenberg et al. 2016). A further argument to support our approach is the fact that students who were not in post-compulsory education in even later years constitute a particular at-risk group (e.g. low PISA skills, mostly low-track attendance, insufficient grades and critical life events such as leaving the parental home, birth or pregnancy; Stalder 2012). 
units. We applied a multilevel approach (using HLM 6.08; Raudenbush et al. 2009) for a simultaneous consideration of both individual and cantonal characteristics (Raudenbush and Bryk 2002).

The dependent variable indicated whether students successfully entered a school- or company-based apprenticeship on upper-secondary level leading to a post-compulsory certification and allowing a qualified entry into the labour market or access to tertiary education (coded as 1 ) or whether they failed (coded as 0; TREE 2013a). As the dependent variable was dichotomous, we specified hierarchical logistic regression models (specified as penalised quasi-likelihood estimation [PQL] with unit-specific effects). This approach was chosen because our research question concerned the variability of individual processes (i. e. students' transition process to upper-secondary education) and its conditions within every single aggregated unit. With regard to the cantonal level, this approach described how the differences in the independent, explanatory level-2 variables were related to differences in level-1 processes.

Predictors on student level referred to person-related (e. g. gender, social background) as well as school- and achievement-related variables and were measured at the end of compulsory school in the year 2000 (Adams and Wu 2002; TREE 2013a). Gender was dummy-coded (reference: girls). School absence (0 no, 1 yes) was included, as students who missed school, skipped classes or arrived late for school once or more in the previous two school weeks were expected to have lower transition chances to upper-secondary education. Because SES proved to have an independent effect on educational outcomes regardless of students' academic achievement (for intercountry differences across Europe cf. e. g. Breen and Jonsson 2005, Pfeffer 2008; for a subnational comparison within Switzerland cf. Stadelmann-Steffen 2011) we also controlled for students' SES, operationalised by the highest socio-economic index (HISEI; Ganzeboom and Treiman 2003), based on parents' statements on their occupation. SES was z-standardised on student level with a mean (M) of 0 and a standard deviation (SD) of 1 . PISA reading literacy (also z-standardised on student level, $M=0, S D=1$ ) was included, as it is generally understood as a core competence to solve real life tasks in everyday situations and to participate in society and is thus a prerequisite of lifelong learning (OECD/PISA 2001). Besides this, students's school marks in Mathematics were included in the analyses, as they might be used as a label of achievement and a means of selection for access to upper-secondary education. The school marks were nominally scaled, distinguishing between students with marks above or at the mark that was required to pass and those students below the pass mark (reference). Finally, due to the stratification of the Swiss secondary school system, the attended track (reference: basic requirements) was also added.

$7 \quad$ Strictly speaking, the attended track is a school-level variable. However, as the effects of interest referred to cantons as aggregate level, the attended track was treated as a level-1 variable and described students' track affiliation. 
Predictors on cantonal level referred to the structural model in lower-secondary education ( 0 streamed model, 1 cooperative or integrated structural model). As previous analyses based on the same dataset, but applying different methodological approaches (Bertschy et al. 2008; Keller et al. 2010; Scharenberg et al. 2016) found significant differences between language regions in Switzerland with regard to students' access to post-compulsory education, acquired certification, gender-typed school-to-work transition and gender segregation at work (Imdorf et al. 2014), we also included further cantonal variables. We also took into account whether students came from the German-speaking part of the country or whether they lived in regions with French or Italian (taken together as Latin Switzerland, reference) as an official language. The transition criteria for access to secondary education indicated whether the cantons apply some form of comparative testing or any other criteria (reference). The degree of urbanisation showed whether students' residential district was urban or rural (reference).

In a first step, the distribution of variance on the two analysis levels was estimated to examine how much of the variance in transition chances from lower- to upper-secondary education can be attributed to individual differences between students and to their cantonal affiliation (empty model). In a second step, we added individual variables (L1 model) that proved to be important for this transition in the analyses by Hupka-Brunner and Wohlgemuth (2014) based on the same dataset. In a third step, we chose a stepwise model specification on aggregate level to identify which of the independent variables provided on cantonal level is of value added for the explanation of the dependent variable: Controlling for individual characteristics, Model 1 only estimated the effect of the structural model and was then maintained in all further model specifications. Model 2 also included the selection criteria for the transition from primary to secondary education. In Model 3, the degree of urbanisation was considered. Model 4 examined the additional effect of the language regions. Model 5 was fully specified on aggregate level and comprised all four cantonal characteristics.

Unlike in simple linear nested models, coefficients in nested logistic regression models are not straightforwardly comparable: Changes in coefficients between different models are not directly attributable to the inclusion of other variables, as the variance in the dependent variable differs between the models (problem of rescaling; Karlson et al. 2012). We therefore chose to interpret only those effects of independent variables within each model (but not across models) which were statistically different from zero $(p \leq 0.05)$.

Deviance statistic based on a likelihood ratio $\chi^{2}$-test $(-2 \mathrm{LL})$ was used to estimate how well a model fitted the data and to compare models that were differently specified on aggregate level. The difference between the Deviance scores of two models has a $\chi^{2}$-distribution. The difference of the degrees of freedom $(d f)$ of two models, in turn, results in a critical $\chi^{2}$-value. If the difference in the Deviance of two models 
is greater than this critical $\chi^{2}$-value, the more complex model leads to a significant improvement of the model fit compared to the simpler model (Langer 2008).

In addition, we conducted a series of robustness checks to validate our findings across different model specifications. These comprised a) simple logistic regression analyses clustering cantonal variables within each canton, b) track-specific analyses comparing academic and basic tracks, separate analyses for c) cantonal structural models and d) language regions, e) controlling for complex sampling procedures and sample attrition by means of panel weights (Sacchi 2011), f) clustering within schools and g) controlling for age, because students who were older than average in their final year of compulsory education might have repeated a grade, which clearly would have limited their likelihood of transition into upper-secondary school, regardless of the prevailing structural model in the canton.

\subsection{Missing data}

For each of the considered variables, the percentage of missing values ranged from 0.1 to 7.4 percent with an average of 1.6 percent. (Multiple) imputation is usually the preferential way of handling missing data compared to pairwise or listwise deletion (Schafer and Graham 2002). Instead of treating missing data as a category of its own, as it was quite common in other sociological studies, missing data in our study were imputed, as our data comprised a set of student background characteristics which could be used in a complex imputation model ${ }^{8}$. Imputation was conducted using the EM algorithm implemented in IBM ${ }^{\circ}$ SPSS ${ }^{\circ}$ Statistics 22 (IBM Corporation 2013). Imputed values were rounded to nearest observed values. The multilevel analyses were based on the imputed dataset.

\subsection{Description of the sample}

The base sample comprised a total of $n=6343$ students participating in the PISA 2000 study in Switzerland who were willing to participate in the TREE panel survey (address survey completed by $54.17 \%$ of the Swiss PISA 2000 sample). Excluding students who did not take part in the first TREE panel wave led to an analysis sample of $n=5528$ students. In order to separate the effects of cantons and language regions, the three bilingual cantons in the sample that belong to two language regions were treated as separate cantons resulting in 27 level-2 units for analysis. ${ }^{9}$ As shown in

8 This imputation model drew on variables correlating with the dependent variable $(r=0.15)$ and comprised i.a. gender, SES, PISA scores, language spoken at home, school track, parental education, students' education and training plans for the next school year, degree of certainty to which these will be realised, match between planned and preferred education or training as well as students' self-expected International Socio-Economic Index of Occupational Status (TREE 2013b).

9 For multilevel analyses, a sample size of at least 30 units at the aggregate level is usually recommended for accurate estimates and standard errors. Simulation studies showed that the sample size at aggregate level is more important than the overall sample size; large level-1 sample sizes, however, partially compensate for small numbers of level-2 groups (Kreft 1996). With regard to 

Table $1 \quad$ Participating cantons by language region and predominant structural model

\begin{tabular}{|c|c|c|c|c|c|c|c|}
\hline \multicolumn{2}{|l|}{ Swiss cantons } & \multirow{3}{*}{$\begin{array}{l}\begin{array}{l}\text { Language } \\
\text { region }\end{array} \\
\text { German }\end{array}$} & \multirow{3}{*}{$\begin{array}{l}\text { Predominant } \\
\text { structural model }\end{array}$} & \multicolumn{4}{|c|}{ Frequencies (\%) } \\
\hline & & & & \multicolumn{2}{|c|}{ Students } & \multicolumn{2}{|c|}{ Schools } \\
\hline Aargau & $(\mathrm{AG})$ & & & 289 & $(5.2)$ & 17 & (5.5) \\
\hline Appenzell-Ausserrhoden & $(A R)$ & German & Streamed & 21 & $(0.4)$ & 1 & (0.3) \\
\hline Basel-Stadt & (BS) & German & $\begin{array}{l}\text { Cooperative, } \\
\text { integrated }\end{array}$ & 71 & $(1.3)$ & 5 & (1.6) \\
\hline Basel-Landschaft & $(\mathrm{BL})$ & German & Streamed & 129 & $(2.3)$ & 5 & (1.6) \\
\hline Bern & (BE) & German & Streamed & 626 & $(11.3)$ & 39 & (12.5) \\
\hline \multirow[t]{2}{*}{ Fribourg } & $(\mathrm{FR})$ & French & Streamed & 361 & $(6.5)$ & 10 & (3.2) \\
\hline & & German & Streamed & 30 & $(0.5)$ & 1 & (0.3) \\
\hline Geneva & (GE) & French & Streamed & 652 & $(11.8)$ & 16 & (5.1) \\
\hline Glarus & $(\mathrm{GL})$ & German & Streamed & 12 & $(0.2)$ & 1 & (0.3) \\
\hline \multirow[t]{2}{*}{ Graubünden } & $(G R)$ & Italian & $\begin{array}{l}\text { Cooperative, } \\
\text { integrated }\end{array}$ & 28 & $(0.5)$ & 2 & (0.6) \\
\hline & & German & Streamed & 56 & $(1.0)$ & 4 & (1.3) \\
\hline Jura & $(J U)$ & French & $\begin{array}{l}\text { Cooperative, } \\
\text { integrated }\end{array}$ & 196 & (3.5) & 10 & (3.2) \\
\hline Lucerne & $(L U)$ & German & Streamed & 100 & $(1.8)$ & 7 & (2.3) \\
\hline Neuchâtel & (NE) & French & $\begin{array}{l}\text { Cooperative, } \\
\text { integrated }\end{array}$ & 245 & (4.4) & 15 & (4.8) \\
\hline Nidwalden & (NW) & German & Streamed & 21 & $(0.4)$ & 1 & (0.3) \\
\hline Obwalden & (OW) & German & Streamed & 59 & (1.1) & 4 & (1.3) \\
\hline Schaffhausen & (SH) & German & Streamed & 42 & $(0.8)$ & 2 & (0.6) \\
\hline Schwyz & $(S Z)$ & German & Streamed & 54 & $(1.0)$ & 3 & (1.0) \\
\hline Solothurn & (SO) & German & Streamed & 71 & $(1.3)$ & 5 & (1.6) \\
\hline St.Gallen & $(\mathrm{SG})$ & German & $\begin{array}{l}\text { Cooperative, } \\
\text { integrated }\end{array}$ & 619 & $(11.2)$ & 32 & (10.3) \\
\hline Thurgau & (TG) & German & Streamed & 82 & (1.5) & 6 & (1.9) \\
\hline Ticino & (TI) & Italian & $\begin{array}{l}\text { Cooperative, } \\
\text { integrated }\end{array}$ & 697 & (12.6) & 30 & (9.6) \\
\hline \multirow[t]{2}{*}{ Valais } & (VS) & French & Streamed & 382 & (6.9) & 22 & (7.1) \\
\hline & & German & Streamed & 17 & $(0.3)$ & 2 & (0.6) \\
\hline Vaud & (VD) & French & Streamed & 319 & $(5.8)$ & 37 & (11.9) \\
\hline
\end{tabular}

Continuation of Table 1 on the next page.

studies analysing the organisational structures of the different cantons in Switzerland, Maas and Hox (2005) explicitly stated that 26 is the minimum required sample size at aggregate level. 
Continuation of Table 1.

\begin{tabular}{|c|c|c|c|c|c|c|}
\hline \multirow[t]{2}{*}{ Swiss cantons } & & \multirow{2}{*}{$\begin{array}{l}\text { Language } \\
\text { region }\end{array}$} & \multirow{2}{*}{$\begin{array}{l}\text { Predominant } \\
\text { structural model }\end{array}$} & \multicolumn{3}{|c|}{ Frequencies (\%) } \\
\hline & & & & & idents & Schools \\
\hline Zug & (ZG) & German & $\begin{array}{l}\text { Cooperative, } \\
\text { integrated }\end{array}$ & 42 & $(0.8)$ & $2 \quad(0.6)$ \\
\hline Zurich & $(\mathrm{ZH})$ & German & Streamed & 307 & (5.6) & $32(10.3)$ \\
\hline Total & & & & 5528 & 00.0) & $311(100.0)$ \\
\hline
\end{tabular}

Notes: The cantons Uri and Appenzell Innerrhoden were not part of the PISA/TREE sample. In Bern, only students from the German-speaking part of the canton participated.

Source: TREE.

Table 1, the streamed model was the prevailing structural model in Switzerland and was mostly applied in the German-speaking cantons. Cooperative, integrated structural models existed in all language regions. Moreover, listing the number of participating schools for each canton revealed that in some small cantons only one school had been sampled.

$19.0 \%$ of students in the analysis sample reported that they had not been in upper-secondary education during the first year after completion of compulsory education. ${ }^{10}$ When students left compulsory school in spring 2000, they were at an average age of $M=15.52$ years $(S D=0.65$, $\min =13, \max =19)$ and $78.9 \%$ were between 15 and 16 years old. 10.4\% spoke a language at home that was not one of the official languages in the country. Students in the analysis sample ( $44.1 \%$ boys) achieved an above-average PISA reading literacy score $(M=516.16$, $S D=87.91$ ), the average highest socio-economic status (HISEI) in their families was $M=50.53$ ( $S D=16.13) .{ }^{11} 33.1 \%$ of the students reported that they had missed school, skipped classes or arrived late for school in the two weeks before the date of the survey. In their last year of compulsory school, students attended a track with either basic $(24.4 \%)$ or extended $(75.6 \%)$ requirements. The analysis sample comprised all three language regions (47.9\% of the students were German-speaking, $39.0 \%$ French-speaking and $13.1 \%$ Italian-speaking). Based on our categorisation of the prevailing structural model in the cantons, we found both categories of the structural model (cooperative/integrated vs. streamed model) in both categories of the language regions (German- vs. French- or Italian-speaking regions). 34.2\% of the students lived in a rural area.

10 A comparable percentage of youths (16.5\%) not attending any certifying upper-secondary education in their first year after the end of compulsory school was reported based on data of the Swiss Federal Surveys of Adolescents ch-x (Keller 2014).

11 Compared to the analysis sample, the base sample showed significantly lower PISA scores $(M=510.01, S D=89.00)$, but a comparable HISEI $(M=50.38, S D=16.28)$. As regards differences in PISA scores, the effect size $(d=0.07)$ indicated negligible differences. 


\section{Results}

Regarding RQ1, the empty model showed that around 10 percent of the variance in students' relative chances of transition from lower- to upper-secondary level was attributable to differences between the cantons ( $\mathrm{ICC}=0.092, p \leq 0.05$, Deviance $=15347.93, d f=26$ ). As this variance proportion was significant (as assumed in $\mathrm{H} 1$ ), it was justified to consider the clustering of students within cantonal units for further analyses. Beyond that, we also examined an empty model with three levels and found significant variance components at each level (student level: $26.9 \%$, school level: $11.0 \%$, cantonal level: $66.2 \%)$. However, the fact that in some cantons only one school has been sampled (see Section 5.4) eliminated the need to analyse two aggregate levels as, in this case, school- and canton-level effects could not have been clearly separated.

Multilevel analyses (Table 2, L1 Model) showed significant gender-specific differences in the transition probability to upper-secondary education: Boys had an almost two times higher chance of transition than girls (OR [Odds Ratio] =1.96). Furthermore, students' social background also mattered even when controlling for PISA score and marks, gender, regular school attendance and track affiliation, showing that students whose social background was one standard deviation above average, had a 1.24 times higher relative chance of transition. Besides that, students with a better initial learning situation, i. e. with PISA scores one standard deviation above average and marks in Mathematics at or above the pass mark, were 1.30 to 1.79 times more likely to gain access to upper-secondary education. In contrast, students who had missed school or classes in their final year of compulsory school were less likely to continue upper-secondary education $(O R=0.77)$. Finally, students' track affiliation in lower-secondary education also had a significant effect on the relative chance of access to upper-secondary education, clearly showing that students in academic tracks were in a relative advantage $(O R=1.81)$. Thus, the findings for the effects of these individual student characteristics quite well reflected the results of the analyses by Hupka-Brunner and Wohlgemuth (2014) which applied a simple logistic regression approach based on the same dataset. The simultaneous inclusion of person-related, socio-economic as well as school- and achievement-related explanatory variables in the level-1 model (Deviance $=14671.38, d f=20$ ) led to a significant improvement of the model fit in comparison to the empty model ( $\Delta$ Deviance $=676.55, \Delta d f=6$, critical $\chi^{2}$-value $\left.=12.59, p \leq 0.05\right)$. However, even when controlling for student variables, the variance proportion on cantonal level remained significant, justifying to inspect effects on aggregate level.

The structural model in lower-secondary education (Model 1 in Table 2, relating to RQ2) was found to have a significant effect on the access to post-compulsory education beyond the effects on student level: Students from cantons with a cooperative or integrated structural model in lower-secondary education had a significantly 


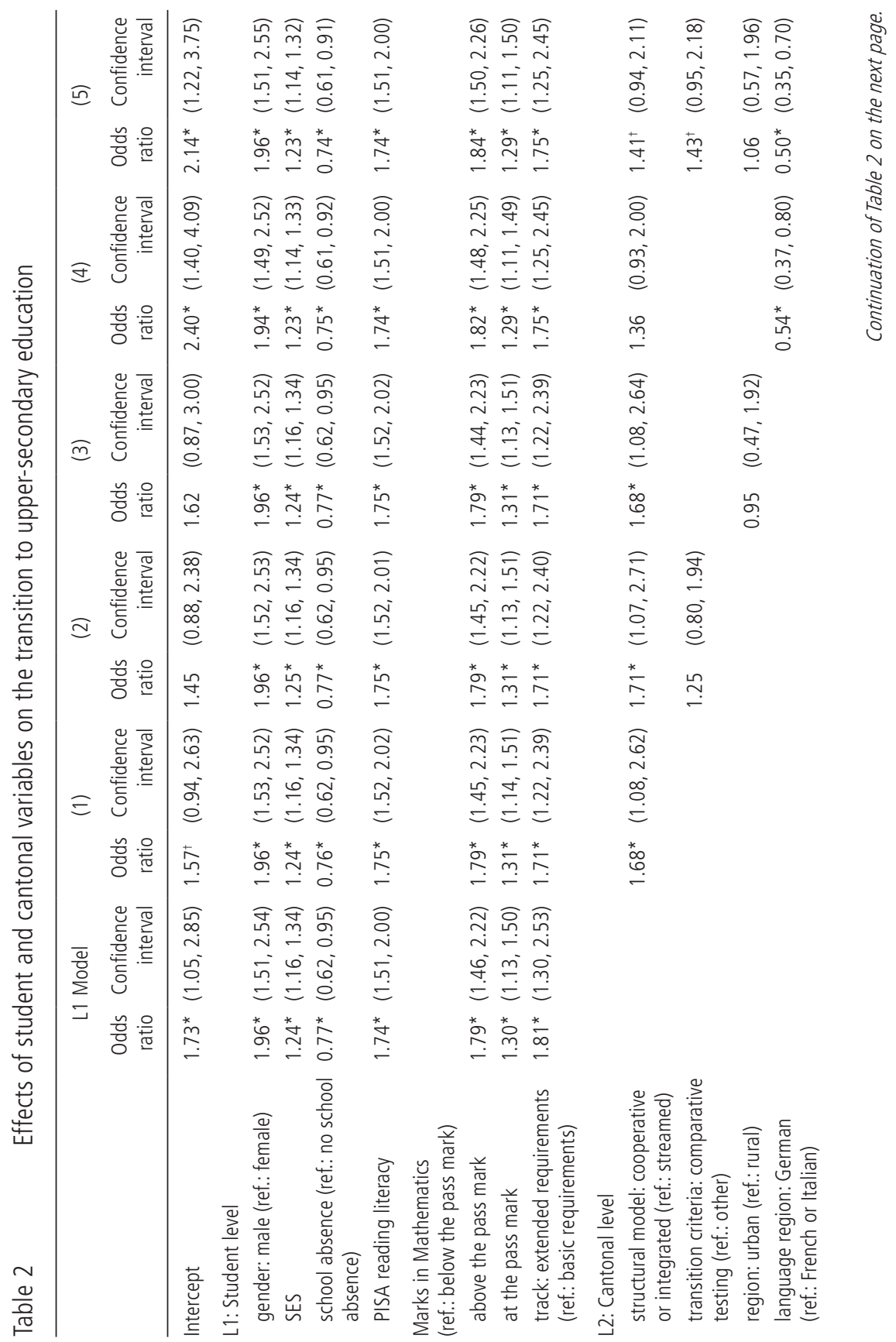




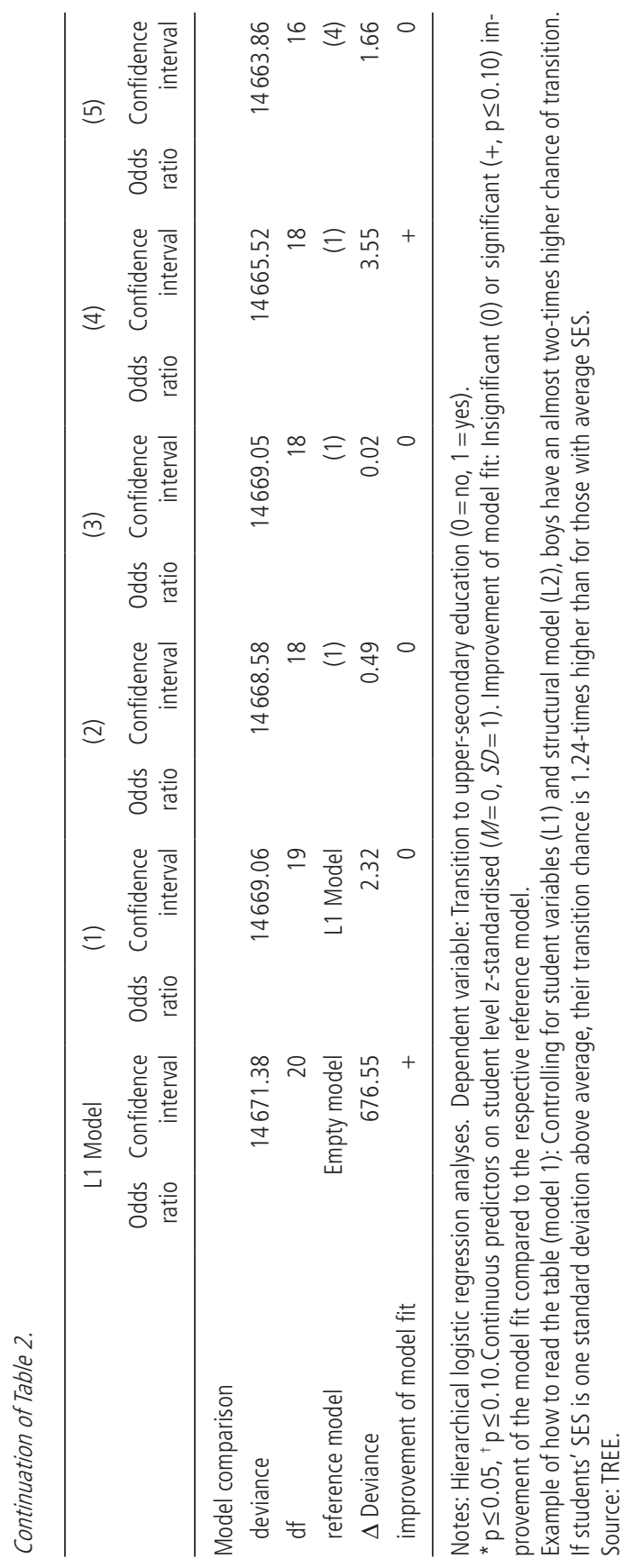


higher relative chance of transition than students from cantons with a streamed structural model $(O R=1.68)$.

Effects of the structural model were still significant when controlling for transition criteria and degree of urbanisation (Models 2 and 3). Cooperative and integrated models seemed to significantly increase the relative chance of a successful transition to upper-secondary education $(1.68 \leq O R \leq 1.71)$. Whether the cantons applied some form of comparative testing when selecting students for secondary school or whether students came from an urban or rural region, did not have significant effects on transition probabilities.

When controlling for language region (Model 4), the effect of the structural model became insignificant $(p=0.107)$. Other things being equal, students from German-speaking Switzerland, however, had a significantly lower relative chance of access to post-compulsory education $(O R=0.54)$ compared to those from the French- or Italian-speaking regions.

Differences between the language regions again arose when comprising all variables of interest on cantonal level in Model 5, emphasising again a clear disadvantage for students from the German-speaking part of Switzerland $(O R=0.50)$. The estimation model, however, also tended to supply careful hints regarding the effects of the structural model $(O R=1.41)$ and the criteria for transition from primary to secondary school $(O R=1.43)$, which seem to have a slight fostering effect on students' transition probability (each with $p \leq 0.10$ ).

Comparing the Models 1 to 5 allowed to identify which kind of specification led to an improvement of the overall model fit. Even though the structural model had a significant effect on students' relative chance of entering upper-secondary education in Model 1, the model fit was, however, not significantly improved compared to the L1 model, as the difference in the Deviance score between these two models was lower than the critical $\chi^{2}$-value $\left(\Delta-2 \mathrm{LL}_{\mathrm{M} 1 \mid \mathrm{L} 1 \text { model }}=2.32 ; \Delta d f=1\right.$, critical $\chi^{2}$-value $\left.=3.84, p=0.124\right)$. The same applied to Models 2 and 3. However, adding the language region in Model 4 slightly improved the model fit compared to Model $1\left(\Delta-2 \mathrm{LL}_{\mathrm{M} 4 \mid \mathrm{M} 1}=3.55 ; \Delta d f=1\right.$, critical $\chi^{2}$-value $=2.71$ if $\left.p \leq 0.10\right)$. The joint consideration of all four aggregate-level variables (Model 5) did not increase of the goodness of fit compared to Model $4\left(\Delta-2 \mathrm{LL}_{\mathrm{M} 5 \mid \mathrm{M} 4}=1.66 ; \Delta d f=2\right.$, critical $\chi^{2}$-value $\left.=5.99, p>0.500\right) .{ }^{12}$

Beyond that, we conducted six kinds of robustness checks to test whether our findings were stable across different model specifications (not in Table 2, for a description see Section 5.2). Simple logistic regression analyses clustering cantonal variables within each canton, track-specific analyses as well as separate estimations for the different kinds of structural models and language regions resulted in significantly higher transition probabilities for students from cantons

12 A simple logistic regression with the same predictors as in Model 5 gave an additional, and not only relative, impression of the overall goodness of fit which was acceptable (Nagelkerke $R^{2}=0.187$ ). 
applying cooperative and integrated structural models $(1.33 \leq O R \leq 2.65 ; p \leq 0.05$; $0.114 \leq R^{2} \leq 0.239$ ). We also applied sample weights (Sacchi 2011) to account for complex sampling procedures in PISA and sample attrition from this baseline study to the first year after the end of compulsory education: Weighted multilevel analyses resulted in slightly higher effects of those variables with $O R>1$ and slightly lower effects of those variables with $O R<1$. In none of these tests, however, direction and significance of the effect of the structural model changed. Similarly, comparing weighted $(w)$ with unweighted $(u)$ multilevel analyses did not improve the model fit $\left(\Delta-2 \mathrm{LL}_{w \mid u}=4.73, d f=2\right.$, critical $\chi^{2}$-value $\left.=5.99, p>0.500\right)$. Finally, adding age to the fully-specified Model 4 as indicator of grade repetition did not have a significant effect $(O R=0.94, p=0.149)$ on students' probability. In summary, these robustness checks underlined the stability of findings from the multilevel analyses.

\section{Discussion}

In Switzerland, the structural organisation of lower-secondary education and the transition to upper-secondary education is up to the responsibility of the 26 cantons. On the one hand, the different prevailing structural models (cooperative, integrated and streamed model) implemented throughout the canton provide differential learning environments. On the other hand, they have a signalling effect for authorities responsible for the selection of students for upper-secondary general education programmes and applicants for vocational education and training. In this way, these cantonal regulations might influence young adults' chances of transition. Thus, the underlying research question of our contribution was whether the cantonal implemented structural model had an effect on the transition to upper-secondary level, and which cantonal structural model provided the highest transition probabilities. We hypothesised that cooperative or integrated models would increase transition probabilities, whereas in cantons with a streamed model, the attended track was assumed to serve as a signal for the selection of applicants leading to disadvantages of certain at-risk students, especially at lower tracks. A multilevel approach was applied to examine effects of student-level and cantonal characteristics.

Based on the Transitions from Education to Employment (TREE) survey with a sample of school leavers, we found with regard to $\mathrm{H} 1$ that students' chance of transition to upper-secondary level significantly varied between the cantons. Person-related characteristics (gender, SES) as well as school- and achievement-related variables (school absence, PISA reading literacy, marks in Mathematics, attended track) were significant predictors of entry into upper-secondary general or vocational education. The significant and strong effect of students' SES, even when controlling for such other background variables, again highlights the well-documented importance of social inequalities for students' educational trajectories and transitions (e.g. Ditton 
and Krüsken 2006; Konietzka 2008; Pfeffer 2008; Maaz et al. 2010b). Beyond that, we found - at least in the trend - that students from cantons with a cooperative or integrated structural model had higher transition probabilities. This consolidated earlier research findings based on the same dataset (Hupka-Brunner and Wohlgemuth 2014), whereas in the present study, we applied a multilevel approach taking into account that students (level 1) are nested within cantons (level 2).

With regard to $\mathrm{H} 2$, we found that the structural model in lower-secondary education on aggregate level had a significant, independent effect on students' relative transition chances into a certifying general or vocational education on uppersecondary level - in fact, over and above the effects on student level: Cooperative and integrated models seem to enable an easier transition compared to streamed models. This is consistent with the results of studies based on different data (e.g. Keller and Moser 2013; Keller 2014) that conversely found that students in cantons applying a streamed model faced greater difficulties of directly entering a certifying upper-secondary education than those in cantons with integrated or cooperative structural models. This finding, however, applied to students attending tracks with basic requirements, indicating an interaction effect between the structural model on cantonal level and track affiliation on student level, whereas there was no independent effect of the structural model. In our study, however, when controlling for the language region, the effect of the structural model was no longer significant. Initial differences in transition rates to upper-secondary education depending on the prevailing structural model in the cantons seem to be superimposed by the effect of the language region. The change in size and significance of the effect of the structural model, controlling for the language region, hints at important underlying cultural and economic differences between the three language regions:

First of all, the structural models proved to be an important factor influencing students' relative transition chances, but the educational system in upper-secondary education is also assumed to play a role. We assume that the apprenticeship market situation, the provision of general and vocational education on upper-secondary level, as well as the proportion of school-based and dual training places may shape transition chances of young people. It seems plausible that these factors are influenced by different cultural norms and economic situations in the language regions. The different, more often school-based academic education systems in the French- or Italian-speaking parts of the country, for instance, provide a smoother continuation of education after compulsory school, whereas students who wish to gain access to VET (most of them in German-speaking Switzerland) need to find an apprenticeship place, which is highly interrelated to the actual labour market situation (Hupka-Brunner et al. 2011a). Thus, the heterogeneous composition of the cantonal aggregate level (e.g. with regard to the share of students opting for general education at upper-secondary level, the status of school-based educations, expectations and aspirations) might also affect students' transition. 
Furthermore, the composition of the structural models in lower-secondary education within the different cantons and language regions seems to be important (Neuenschwander et al. 2012), but could not be controlled for in our analyses as the EDK survey only provided information on the most prevailing school model and some cantons apply more than one structural model with different implementations (see Section 3.1). Beyond that, it seems plausible that the composition of lowersecondary education and its permeability are also influenced by cultural differences between the language regions.

As an implication for future research, we derive from our findings that it would be necessary to conduct further differentiated analyses separately for the three language regions. But, at the same time, one would also encounter statistical and methodological limits, as such an approach would strongly restrict the number of analysis units on aggregate level. A further conclusion to be drawn from our study concerns the classification of the cantons with regard to the adopted structural model. It partly led to a simplification of the data structure, as it only displayed the respectively prevailing structural model. Future research should thus examine the heterogeneity within the cantons and students' educational situation at upper-secondary level. It should also - besides individual and cantonal variables on micro- and macro-level - take into account further characteristics on a meso-level (such as school or classroom level) and try to disentangle the complex interlock of relevant analysis levels.

\section{References}

Adams, Ray J., and Margaret Wu. 2002. PISA 2000 Technical Report. Paris: OECD.

Autorengruppe Bildungsberichterstattung (ed.). 2008. Bildung in Deutschland 2008. Ein indikatorengestützter Bericht mit einer Analyse zu Übergängen im Anschluss an den Sekundarbereich I. Bielefeld: Bertelsmann.

Baeriswyl, Franz, Ulrich Trautwein, Christian Wandeler, and Oliver Lüdtke. 2009. Wie gut prognostizieren subjektive Lehrerempfehlungen und schulische Testleistungen beim Übertritt die Mathematik- und Deutschleistung in der Sekundarstufe I? Zeitschrift für Erziehungswissenschaft Sonderheft 12-09: 352-372.

Baumert, Jürgen, Petra Stanat, and Rainer Watermann. 2006. Schulstruktur und die Entstehung differenzieller Lern- und Entwicklungsmilieus. Pp. 95-188 in Herkunftsbedigte Disparitäten im Bildungswesen: Differenzielle Bildungsprozesse und Probleme der Verteilungsgerechtigkeit. Vertiefende Analysen im Rahmen von PISA 2000, edited by Jürgen Baument, Petra Stanat, and Rainer Watermann. Wiesbaden: VS Verlag.

Becker, Rolf. 2011. Entstehung und Reproduktion dauerhafter Bildungsungleichheiten. Pp. 87-138 in Lehrbuch der Bildungssoziologie, edited by Rolf Becker. Wiesbaden: VS Verlag.

Bertschy, Kathrin, Edi Böni, and Thomas Meyer. 2008. Young People in Transition from Education to Labour Market. Basel: TREE, http://www.tree.unibe.ch/e206328/e305140/e305154/files307441/ Bertschy_Boeni_Meyer_2007_Results_Update_en_ger.pdf (29.02.2016). 
Blossfeld, Hans-Peter, Jutta von Maurice, and Thorsten Schneider. 2011. The National Educational Panel Study: Need, Main Features, and Research Potential. Zeitschrift für Erziehungswissenschaft 14(2): 5-17.

Boudon, Raymond. 1974. Education, Opportunity, and Social Inequality. Changing Prospects in Western Society. New York: Wiley.

Bourdieu, Pierre. 1983. Ökonomisches Kapital, kulturelles Kapital, soziales Kapital. Pp. 183-198 in Soziale Ungleichheiten, edited by Reinhard Kreckel. Göttingen: Schwartz.

Bourdieu, Pierre, and Jean-Claude Passeron. 1971. Die Illusion der Chancengleichheit. Untersuchungen zur Soziologie des Bildungswesens am Beispiel Frankreichs. Stuttgart: Klett.

Breen, Richard, and Jan O. Jonsson. 2005. Inequality of Opportunity in Comparative Perspective: Recent Research on Educational Attainment and Social Mobility. Annual Review of Sociology 31(1): 223-243.

Brosziewski, Achim, and Miriam Nido. 2005. Leistung und Herkunft in integrativen, kooperativen und getrennten Schulmodellen. Pp. 141-162 in PISA 2003: Analysen für Deutschschweizer Kantone und das Fürstentum Liechtenstein. Detaillierte Ergebnisse und methodisches Vorgehen, edited by Forschungsgemeinschaft PISA Deutschschweiz/FL. Zurich: Forschungsgemeinschaft PISA Deutschschweiz/FL.

Büchler, Theresa. 2016. Schulstruktur und Bildungsungleichheit: Die Bedeutung von bundeslandspezifischen Unterschieden beim Übergang in die Sekundarstufe I für den Bildungserfolg. Kölner Zeitschrift für Soziologie und Sozialpsychologie 68(1): 53-87.

Buchmann, Marlis, and Irene Kriesi. 2010. Schuleintritt und Schulleistungen im mittleren Primarschulalter. Schweizerische Zeitschrift für Soziologie 36(2): 325-344.

Coradi Vellacott, Maja, and Stefan C. Wolter. 2005. Chancengerechtigkeit im Schweizerischen Bildungswesen. Aarau: Schweizerische Koordinationsstelle für Bildungsforschung.

Ditton, Hartmut, and Jan Krüsken. 2006. Der Übergang von der Grundschule in die Sekundarstufe I. Zeitschrift für Erziehungswissenschaft 9(3): 348-372.

Ditton, Hartmut, and Kai Maaz. 2011. Sozio-ökonomischer Status und soziale Ungleichheit. Pp. 193-208 in Empirische Bildungsforschung, edited by Heinz Reinders, Hartmut Ditton, Cornelia Gräsel, and Burkhard Gniewosz. Wiesbaden: VS Verlag.

Eberhard, Verena, and Joachim G. Ulrich (eds.). 2010. Übergänge zwischen Schule und Berufsausbildung. Wiesbaden: VS Verlag.

Eckert, Thomas (ed.). 2007. Übergänge im Bildungswesen. Münster: Waxmann.

Elder, Glen H. Jr. 1975. Age Differentiation and the Life Course. Annual Review of Sociology 1(1): 165-190.

FSO (Federal Statistical Office). 2003. Wege in die nachobligatorische Ausbildung. Die ersten zwei Jahre nach Austritt aus der obligatorischen Schule. Zwischenergebnisse des Jugendlängsschnitts TREE. Neuchâtel: Bundesamft für Statistik.

FSO (Federal Statistical Office). 2014. Bildungssystem Schweiz - Indikatoren. Verläufe und Übergänge Selektion auf der Sekundarstufe I. http://www.bfs.admin.ch/bfs/portal/de/index/themen/15/17/ blank/01.indicator.404204.4024.html?open=104\#104 (05.04.2015).

Ganzeboom, Harry B. G., and Donald J. Treiman. 2003. Three Internationally Standardised Measures for Comparative Research on Occupational Status. Pp. 159-193 in Advances in Cross-National Comparison. A European Working Book for Demographic and Socio-Economic Variables, edited by Jürgen H. P. Hoffmeyer-Zlotnik and Christof Wolf. New York: Kluwer Academic Press.

Gentinetta, Peter, and Madeleine Zulauf. 2001. Eine Bildungsstufe im Umbruch. Panorama 2001(1): $40-42$.

Geser, Hans. 2003. Beruf und Bildung diesseits und jenseits der Saane. Panorama 2003(3): 39-41.

Hillmert, Steffen 2004. Soziale Ungleichheiten im Bildungsverlauf: Zum Verhältnis von Bildungsinstitutionen und Entscheidungen. Pp. 69-97 in Bildung als Privileg? Erklärungen und Befunde zu den 
Ursachen der Bildungsungleichheit, edited by Rolf Becker and Wolfgang Lauterbach. Wiesbaden: VS Verlag.

Hupka-Brunner, Sandra, Thomas Meyer, Barbara E. Stalder, and Anita Keller. 2011a. PISA-Kompetenzen und Übergangswege: Ergebnisse der Schweizer TREE Studie. Pp. 175-190 in Neue Jugend, neue Ausbildung, edited by Elisabeth M. Krekel and Tilly Lex. Bielefeld: Bertelsmann.

Hupka-Brunner, Sandra, Stefan Sacchi, and Barbara E. Stalder. 2010. Social Origin and Access to Upper Secondary Education in Switzerland: A Comparison of Company-Based Apprenticeship and Exclusively School-Based Programmes. Swiss Journal of Sociology 36(1): 11-31.

Hupka-Brunner, Sandra, Robin Samuel, Eveline Huber, and Manfred M. Bergman. 2011b. Geschlechterungleichheiten im intergenerationalen Bildungstransfer in der Schweiz. Pp. 77-97 in Geschlechtsspezifische Bildungsungleichheiten. Betrachtungen von Geschlechterunterschieden im Bildungserfolg aus Sicht verschiedener sozialwissenschaftlicher Studien, edited by Andreas Hadjar. Wiesbaden: VS Verlag.

Hupka-Brunner, Sandra, and Karin Wohlgemuth. 2014. Wie weiter nach der Schule? Zum Einfluss der Selektion in der Sekundarstufe I auf den weiteren Bildungsverlauf Schweizer Jugendlicher. Pp. 99-109 in Selektion in Schule und Arbeitsmarkt. Forschungsbefunde und Praxisbeispiele, edited by Markus P. Neuenschwander. Zurich: Rüegger.

IBM Corporation. 2013. IBM SPSS Missing Values 22. ftp://public.dhe.ibm.com/software/analytics/spss/ documentation/statistics/20.0/en/client/Manuals/IBM_SPSS_Missing_Values.pdf (05.04.2015).

Imdorf, Christian 2009. Die betriebliche Verwertung von Schulzeugnissen bei der Ausbildungsstellenvergabe. Empirische Pädagogik 23(4): 392-409.

Imdorf, Christian, Stefan Sacchi, Karin Wohlgemuth, Sasha Cortesi, and Aline Schoch. 2014. How Cantonal Education Systems in Switzerland Promote Gender-Typical School-to-Work Transitions. Swiss Journal of Sociology 40(2): 175-196.

Karlson, Kristian B., Anders Holm, and Richard Breen. 2012. Comparing Regression Coefficients between Same-Sample Nested Models Using Logit and Probit: A New Method. Sociological Methodology 42(1): 286-313.

Keller, Anita, Sandra Hupka-Brunner, and Thomas Meyer. 2010. Post-Compulsory Education Pathways in Switzerland: The First Seven Years. Basel: TREE, http://www.tree.unibe.ch/e206328/e305140/ e305154/files305376/Keller_Hupka_Meyer_2010_Results_Update_en_ger.pdf (29.02.2016).

Keller, Florian. 2014. Strukturelle Faktoren des Bildungserfolgs. Wie das Bildungssystem den Übertritt ins Berufsleben bestimmt. Wiesbaden: Springer VS.

Keller, Florian, and Urs Moser. 2013. Schullaufbahnen und Bildungserfolg. Auswirkungen von Schullaufbahn und Schulsystem auf den Übertritt ins Berufsleben. Zurich: Rüegger.

Konietzka, Dirk. 2008. Berufliche Ausbildung und der Übergang in den Arbeitsmarkt. Pp. 277-306 in Bildung als Privileg. Erklärungen und Befunde zu den Ursachen der Bildungsungleichheit, edited by Rolf Becker and Wolfgang Lauterbach. Wiesbaden: VS Verlag.

Kreft, Ita G. G. 1996. Are Multilevel Techniques Necessary? An Overview, Including Simulation Studies. Unpublished Report, California State University, Los Angeles, http://files.eric.ed.gov/fulltext/ ED371033.pdf (06.05.2015).

Kronig, Winfried. 2007. Die systematische Zufälligkeit des Bildungserfolgs. Theoretische Erklärungen und empirische Untersuchungen zur Lernentwicklung und Leistungsbewertung in unterschiedlichen Schulklassen. Bern: Haupt.

Langer, Wolfgang 2008. Mehrebenenanalyse. Eine Einführung für Forschung und Praxis. Second edition. Wiesbaden: VS Verlag.

Levy, René, Paolo Ghisletta, Jean-Marie Le Goff, Dario Spini, and Eric Widmer. 2005. Towards an Interdisciplinary Perspective on the Life Course. Amsterdam: JAI Press.

Maas, Cora J. M., and Joop J. Hox. 2005. Sufficient Sample Sizes for Multilevel Modelling. Methodology 1(3): 86-92. 
Maaz, Kai, Jürgen Baumert, Cornelia Gresch, and Nele McElvany. 2010a. Der Übergang von der Grundschule in die weiterführende Schule: Leistungsgerechtigkeit und regionale, soziale und ethnisch-kulturelle Disparitäten. Berlin: Bundesministerium für Bildung und Forschung (BMBF).

Maaz, Kai, Jürgen Baumert, and Ulrich Trautwein 2010b. Genese sozialer Ungleichheit im institutionellen Kontext der Schule: Wo entsteht und vergrößert sich soziale Ungleichheit? Pp. 69-102 in Bildungsungleichheit revisited. Bildung und soziale Ungleichheit vom Kindergarten bis zur Hochschule, edited by Heinz-Hermann Krüger, Ursula Rabe-Kleberg, Rolf-Thorsten Kramer, and Jürgen Budde. Wiesbaden: VS Verlag.

Moser, Urs. 2004. Jugendliche zwischen Schule und Berufsbildung. Eine Evaluation bei Schweizer Grossunternehmen unter Berücksichtigung des internationalen Schulleistungsvergleichs PISA. Bern: h.e.p.

Moser, Urs. 2008. Schulsystemvergleich: Gelingensbedingungen für gute Schulleistungen. Expertise über die Bedeutung von Schulmodellen für die Entwicklung der Schulleistungen. Zurich: Institut für Bildungsevaluation.

Moser, Urs, Heinz Rhyn, and Sarah Tresch. 2002. Jugendliche zwischen Schule und Berufsbildung. Qualifikationen und Berufsperspektiven Jugendlicher am Ende der Volksschule im Vergleich zu Erwartungen und Anforderungen von Berufsschulen und Betrieben. Pp. 186-191 in Forum Bildung und Beschäftigung. Workshop-Dokumentation. Arbeitsbericht 29, edited by Franz Horvath. Bern: Nationales Forschungsprogramm Bildung und Beschäftigung (NFP 43).

Moser, Urs, Margrit Stamm, and Judith Hollenweger (eds.). 2005. Für die Schule bereit? Lernstandserhebung beim Eintritt in die ersten Klassen des Kantons Zürich. Oberentfelden: Sauerländer.

Neuenschwander, Markus, Michelle Gerber, Nicole Frank, and Benno Rottermann. 2012. Schule und Beruf. Wege in die Erwerbstätigkeit. Wiesbaden: VS Verlag.

OECD/PISA (ed.). 2001. Knowledge and Skills for Life. First Results from PISA 2000. Paris: OECD.

Pfeffer, Fabian T. 2008. Persistent Inequality in Educational Attainment and its Institutional Context. European Sociological Review 24(5): 543-565.

Raudenbush, Stephen W., and Anthony S. Bryk. 2002. Hierarchical Linear Models. Second edition. Thousand Oaks, CA: Sage.

Raudenbush, Stephen W., Anthony S. Bryk, and Richard Congdon. 2009. HLM 6.08 for Windows. Computer software. Lincolnwood, IL: Scientific Software International, Inc.

Sacchi, Stefan. 2011. Construction of TREE Panel Weights: Documentation for the Panel Waves from 2000 to 2010. Basel and Zurich: TREE and cue sozialforschung, http://www.tree.unibe.ch/ e206328/e305140/e305154/files305335/Sacchi_2013_TREE_longitudinal_weights_en_ger. pdf (29.02.2016).

SCCRE (Swiss Coordination Centre for Research in Education) (ed.). 2010. Bildungsbericht Schweiz 2010. Aarau: Schweizerische Koordinationsstelle für Bildungsforschung.

Schafer, Joseph L., and John W. Graham. 2002. Missing Data: Our View of the State of the Art. Psychological Methods 7(2): 147-177.

Scharenberg, Katja, Melania Rudin, Barbara Müller, Thomas Meyer, and Sandra Hupka-Brunner. 2016. Education Pathways from Compulsory School to Young Adulthood: The First Ten Years. Pp. 20-45 in Transitions in Youth and Young Adulthood: Results from the Swiss TREE Panel Study, edited by Katja Scharenberg, Sandra Hupka-Brunner, Thomas Meyer, and Manfred Max Bergman. Zurich: Seismo.

Seibert, Holger, Sandra Hupka-Brunner, and Christian Imdorf. 2009. Wie Ausbildungssysteme Chancen verteilen - Berufsbildungschancen und ethnische Herkunft in Deutschland und der Schweiz unter Berücksichtigung des regionalen Verhältnisses von betrieblichen und schulischen Ausbildungen. Kölner Zeitschrift für Soziologie und Sozialpsychologie 61(4): 595-620.

Stadelmann-Steffen, Isabel. 2007. Der Einfluss der sozialpolitischen Kontexte auf die Frauenerwerbstätigkeit in der Schweiz. Kölner Zeitschrift für Soziologie und Sozialpsychologie 59(4): 589-614. 
Stadelmann-Steffen, Isabel. 2011. Education Policy and Educational Inequality - Evidence from the Swiss Laboratory. European Sociological Review 28(3): 379-393.

Stalder, Barbara E. 2012. Kritische Transitionen in der beruflichen Grundbildung: Wenn Ausbildungswege nicht der Norm entsprechen. Pp. 94-105 in Diagnostik und Prävention von Ausbildungsabbrüchen in der Berufsbildung, edited by Carmen Baumeler, Bernd-Joachim Ertelt, and Andreas Frey. Landau: Verlag Empirische Pädagogik.

Swiss Document Server Education Edudoc.ch. 2009. Grundlegende Informationen zum Bildungswesen. http://edudoc.ch/record/32390?ln=de (04.05.2015).

Swiss Education Server. 2016. Lower-secondary education. http://swisseducation.educa.ch/en/lowersecondary-education (04.05.2015).

Trautwein, Ulrich, Olaf Köller, Rainer Lehmann, and Oliver Lüdtke (eds.). 2007. Schulleistungen von Abiturienten: Regionale, schulformbezogene und soziale Disparitäten. Münster: Waxmann.

TREE. 2013a. Codebook TREE Survey Panel 2001. Release 2013. Basel: TREE.

TREE. 2013b. Concepts and Scales. Survey Waves 1-8, 2001-2010. Basel: TREE, http://www.tree.unibe. ch/e206328/e305140/e305154/files305246/TREE_2013_Concepts_Scales_English_ger.pdf (29.02.2016).

TREE. 2013c. TREE Project Documentation 2000-2012. Basel: TREE, http://www.tree.unibe.ch/e206328/ e305140/e305154/files305251/TREE_2013_e_Project_docu_2000-2012_ger.pdf (29.02.2016).

Ulrich, Joachim G. 2012. Institutionelle Mechanismen der (Re-)Produktion von Bildungsungleichheit an der Schwelle zur dualen Berufsausbildung und ihr Einfluss auf die Qualifizierungschancen von Bewerbern mit Migrationshintergrund. Pp. 68-84 in Soziale Ungleichheit in der Einwanderungsgesellschaft. Kategorien, Konzepte, Einflussfaktoren, Tagungsdokumentation im Auftrag der Abteilung Wirtschafts- und Sozialpolitik der Friedrich-Ebert-Stiftung, edited by Patricia Pielage, Ludger Pries, and Günter Schultze. Bonn: Friedrich-Ebert-Stiftung. 


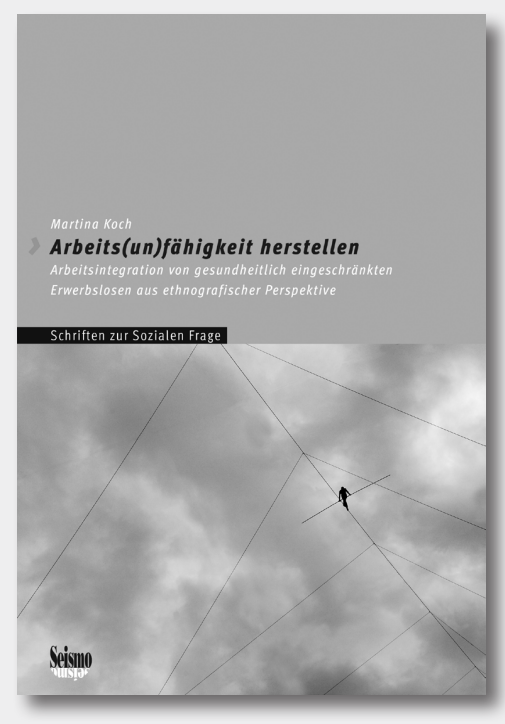

Wie in den meisten entwickelten Ländern ist auch in der Schweiz zu beobachten, dass zunehmend Menschen mit gesundheitlichen Einschränkungen und «Behinderungen» aktiviert und beruflich integriert werden sollen. Die immer stärker vorgetragene politische Forderung, Menschen mit gesundheitlichen Einschränkungen beruflich einzugliedern, stellt die einschlägigen Institutionen und Fachkräfte vor grosse Herausforderungen. In der Folge vervielfältigen sich entsprechende Praktiken, während die Instrumente und Methoden zur Feststellung von Arbeits(un)fähigkeit verfeinert werden. Anhand einer Ethnografie in zwei kantonalen Arbeitsintegrationsagenturen geht

\section{Martina Koch}

\section{Arbeits(un)fähigkeit herstellen}

Arbeitsintegration von

gesundheitlich einge-

schränkten Erwerbslosen aus
ethnografischer Perspektive

Reihe

«Schriften zur Sozialen Frage»

268 Seiten, SFr. 38.-

diese Studie der Frage nach, wie die untersuchten Organisationen die Arbeits-

(un)fähigkeit ihrer KlientInnen konstruieren und bearbeiten. Im Fokus stehen die organisationalen Problematisierungs- und Bearbeitungsstrategien und dahinterstehende Logiken.

Martina Koch, Dr. rer. soc., promovierte an der Universität St. Gallen. Sie ist Soziologin und arbeitet als wissenschaftliche Mitarbeiterin an der Hochschule für Soziale Arbeit der Fachhochschule Nordwestschweiz (FHNW), wo sie in den Bereichen Sozialstaat und Sozialpolitik, Erwerbslosigkeit und Arbeitsintegration sowie Diversität in der öffentlichen Verwaltung forscht. 